\title{
Hireling Strangers and the Wandering Throne: Ireland, Scotland and Samuel Ferguson ${ }^{1}$
}

\author{
Colin Graham \\ NUI Maynooth
}

Copyright (c) 2009 by Colin Graham. This text may be archived and redistributed both in electronic form and in hard copy, provided that the author and journal are properly cited and no fee is charged.

\begin{abstract}
This essay discusses the evolving literary and cultural relationship between Ireland and Scotland in the writings and career of the nineteenth-century Irish poet Samuel Ferguson. By examining the correspondence between Ferguson and his Edinburgh-based publisher, Blackwood's Edinburgh Magazine, it shows the ways in which Ferguson tried to frame his own youthful politics through the Scottish Toryism of Blackwood's. Ferguson's temporary interest in the Young Ireland movement and the Protestant Repeal Association in the 1840s is brought to an end in his poem and essay on the death of Thomas Davis. The essay argues that this poem, and the account of Davis which accompanies it, are modelled on the two essays that Ferguson wrote in 1845 on the Scottish poet Robert Burns. Ferguson's strategy of reading Burns as a respectable poet with a naturally conservative sensibility is replicated in his account of Davis. The essay then suggests that in his later work Ferguson found that Scotland was both an awkward analogy for Ireland's political situation and less welcoming site of publication for his version of Ireland than had been the case at the beginning of his career. His epic poem Congal (1872) shows the Irish-Scottish relationship under strain, as does his final correspondence with Blackwood's.
\end{abstract}

Keywords. Samuel Ferguson, Scotland, Congal, Thomas Davis, Robert Burns, Blackwood's Edinburgh Magazine.

Resumen. Este artículo analiza la evolución de las relaciones literarias y culturales entre Irlanda y Escocia en los escritos y la carrera del poeta irlandés del siglo XIX Samuel Ferguson. Mediante el examen de la correspondencia entre Ferguson y su editorial de Edimburgo, Blackwood's Edinburgh Magazine, se muestra como Ferguson intentó encauzar su política juvenil a través del conservadurismo escocés de Blackwood's. El interés que Ferguson mostró temporalmente por el movimiento de La Joven Irlanda y por la Asociación protestante para la derogación del Acta de Unión en la década de 1840 finaliza en su poema y ensayo sobre la muerte de Thomas Davis. El artículo sostiene que este poema, y el relato sobre Davis que lo acompaña, se inspiran en los dos ensayos que Ferguson escribió en 1845 sobre el poeta escocés Robert Burns. La estrategia de Ferguson de considerar a Burns como un respetable poeta con una sensibilidad conservadora innata se repite en su apreciación de Davis. El artículo sugiere también que en su obra posterior Ferguson descubrió que Escocia era una torpe analogía de la situación política de Irlanda, así como un lugar menos propicio para la publicación de su versión de Irlanda de lo que había sido al comienzo de su carrera. En el poema épico Congal (1872) se muestra una relación gaélico-escocesa en tensión, así como también en su última correspondencia con Blackwood's.

Palabras clave. Samuel Ferguson, Scotland, Congal, Thomas Davis, Robert Burns, Blackwood's Edinburgh Magazine.

1. Research for this essay was aided by a Leverhulme grant from the Institute for Advanced Studies in the Humanities at Edinburgh University. I am especially grateful to Professor Cairns Craig for his support.

ISSN 1699-311X 
In Samuel Ferguson's epic poem Congal, published in 1872, there are several curious moments of anachronism, where the archaic time of legend slips out of joint, and the poem gets distracted by its author's contemporary obsessions. It is no accident that the most obvious of these chronological fractures in the poem arises from Ferguson's attempt to settle the awkward play of Ireland against Scotland, the Gael with and against the Pict. In Congal Scottish troops help with the re-invasion of Ireland by Congal, the King of Ulster. Meanwhile, flitting across the text of Congal, in and out of its narrative and its scholarly notes, is the figure of mad King Sweeney, that ancient Irish-Scottish traveller, who later in the textual life of Irish literature cuts his swathe across the pages of Flann O'Brien's At SwimTwo-Birds and Seamus Heaney's translation Sweeney Astray. As Heaney has it, Sweeney's is a story of "fits and trips" and "frenzies" (Heaney 1984: 3) - in Ferguson's poem, Sweeney's adventures are "Mad-Freaks" (Ferguson 1872: 234), and their frantic energy is a danger to the poem's epic and cultural coherence. Sweeney is both part of, and more broadly symbolic of, Ferguson's uncertain Celtic politics, a set of negative analogies which broadly align the various cultures of the Celts, which Celticise England, and which continually separate Ireland and Scotland while talking of them in the same breath. Ferguson's interactions with Scottish culture were many and various - they range from the opportunism of a young writer finding an outlet for his work, through a search for a genuine cultural solidarity, to a potential place for the confirmation of Tory unionism, and eventually a wariness of Scotland's similarity to Ireland which was unsurprisingly a defence of Ireland's particularity. Ferguson's continual movement towards Scotland was both a fitful reassessment of his Belfast and Antrim roots and an increasingly bad-tempered admission of Scotland's existence as a cultural centre of the type that Ferguson assumed Ireland had not fully become in his lifetime. For Ferguson, Scotland offered models for Irish intellectual development, for some shared history, and most obviously for a way to assert Celtic difference safely within the remit of what Ferguson, unoriginally, called "the ThreeJoined-Realm” (Ferguson 1872: 107) of imperial Britain.
Scotland's importance moves in and out Ferguson's work, with a Sweeney-like restlessness - lying beyond the occasionally genetic, historical, and material equivalences which Ferguson's multifarious writings make between Ireland and Scotland is always the desire for Ireland itself to be intellectually rooted, "racy of the soil" to use the Young Ireland phrase, with its own literary and intellectual culture and its politics left to mature, as Ferguson desired, within the Union. This projected ideological future for an Ireland at once British and Irish finds its haunting shade in Ferguson's idealisation of Robert Burns as poet and ploughman, an ideally organic and local intellectualism which Ferguson sees Ireland drifting away from after the death of Thomas Davis and the famine.

Samuel Ferguson was born in Belfast in 1810 and died in Dublin in 1886. His family were a mixture of small-landed farmers in Antrim and professionals in Belfast. As his poem "Willy Gilliland" (Ferguson 1836) later showed, he traced his family origins back to convenanting Scotland and thus included some embattled form of Protestantism in his identity. In later life, through his work in the judicial system, the Royal Irish Academy, and his marriage, his acceptance into a slightly different stratum of Irish Protestantism, and specifically Anglicanism, in Dublin lead him to identify less with the regional affinities of Ulster, and less too with the Presbyterian heritage of his family - this in turn was to alter his perception of Scotland's importance, an imperial framework for Ireland and Scotland eventually taking the place of more local arguments. Ferguson was educated at the relatively liberal Protestant school, the Royal Belfast Academical Institution, which not many years before had been associated with the more rarefied echelons of the United Irishmen, though post-Union it mirrored the almost uniform transition in the North towards Protestant unionism; Ferguson then studied at Trinity College Dublin, though he never actually graduated. He later attended Lincoln's Inns in London, and it was during this time, in his early twenties, that he began his literary connections with Scotland, sending poetry to Blackwood's Edinburgh Magazine, having previously published only in the short-lived, Belfast-based Ulster Magazine. His appearance in Blackwood's came as something of a surprise to him, and indeed some of the hubris 
which Ferguson occasionally revealed throughout his long literary career had its origins at the point at which 'the Professor', Christopher North (a pseudonym for John Wilson), indulged Ferguson's poem 'The Forging of the Anchor' (Ferguson 1832a). For some years Blackwood's and the Dublin University Magazine were Ferguson's main publishing outlets, for both poetry and fiction. (One of the curiosities about Ferguson's early career is that his appearances in Blackwood's mirrors the early publication history of W.B. Yeats, who used his connections with W.E. Henley, and the sometimes not very Scottish Scots Observer, in a similar way). The Dublin University Magazine, published out of Trinity, gave Ferguson a respectable Irish outlet for his poetry and prose, and honed his politic views, at least early in his life. John P. McBride describes the Dublin University Magazine as being a "missionary of Victorian civilization defending the [Irish] nation against the Trojan horse of radical politics and innovation; yet it would also oppose English cultural oppression by seeking to inspire and reflect Irish achievement and talent” (McBride 1987: 59$60)$. The mixture of pro-union conservatism and knee-jerk patriotism in Dublin University Magazine set the foundations for Ferguson's ideological future; the magazine's often uncompromising political analysis, fiction and poetry was closely modelled on Blackwood's, and Ferguson's contributions there stood him in good stead with the new editors of Dublin University Magazine.

Through the 1830s and 1840s Ferguson's body of poetry, prose and criticism increased, mainly through these two magazines. While juggling his writing with his career as a circuit magistrate Ferguson was restricted to short reviews and stories, and during the pre-famine decades he veered between his Edinburgh and Dublin publishers, occasionally falling out with both - when the Dublin University Magazine was Irish in the wrong way he swayed towards Blackwood's; his correspondence with Blackwood's suggests that when rejected in Edinburgh he assumed his writing was deemed "to [sic] Irish" (Ferguson 1843b). Ferguson dallied to a limited extent with the rising fortunes of the Young Ireland movement in the early years of the 1840s, as he searched for a mode in which to express his Protestant patriotism, leading eventually to his involvement in the founding of the Protestant Repeal Association (see Patten 2004: 99-130). His delayed obituary article and poem on the death of Thomas Davis, published in Dublin University Magazine in 1847 (Davis having died in 1845), is the point (at least in print) at which he comes closest to a nationalist politics, trying to take Davis's legacy with him as an insurance policy for Protestantism. This pivotal moment in Ferguson's cultural trajectory, when he recuperates Davis to suit his own ends, was foreshadowed by the articles Ferguson had written two years earlier in Dublin University Magazine on the poetry and life of Robert Burns (discussed further below). Over the succeeding decades Ferguson's politics become less clear cut, at least in terms of his views on Repeal as he moved more and more into establishment forms of cultural nationalism, becoming Deputy Keeper of the Records of Ireland in 1867, and in 1876 VicePresident of the Royal Irish Academy. These two appointments tell of what is probably Ferguson's greater, though less individually distinct, cultural legacy. His researches into what he would call Irish antiquities, and the way in which he was able to use these resources across the spectrum of his activities, from his conviction in the distinctive nature of Ireland's material heritage, to his poems on Irish mythology and legend, provide the bridge between the pseudo-Orientalist Irish scholarship predominant in the early decades of the nineteenth century and the broad body of work which makes up the early period of the Irish Literary Revival at the end of the century. Arguably it is here also that his contacts with Scotland play the most important role, since his eclectic sense of proper intellectual activity glances continually to Edinburgh, and more particularly to what Eve Patten argues is his civic ideal, significantly derived from the Scottish enlightenment (Patten 2004).

Ferguson's writings are remarkable for their refusal to stay restricted to one genre; he was an expert, for example, on Ogham inscriptions (on which he gave a series of lectures at Edinburgh University in 1884, at the age of 74); he also wrote on architecture, ancient and contemporary; on fortifications and burial chambers. In his more bizarrely polymathic moments he sent unpublishable, or at least unpublished, articles to Blackwood's. One enthused on the short-lived and experimental atmospheric railway running up Dalkey Hill 
south of Dublin (short-lived because the leather valves used for propulsion were eaten by rats, and the venture in general proved too expensive to be viable) (Ferguson 1843a); and, in the midst of a skit on entrepreneurial industrialists, he drew up plans for a tunnel under the Thames, for which he rather comically supplied measurements with great confidence ("NB You may depend, I think, on the accuracy of the calculations") and then panicked four days later, hurriedly writing to Blackwood's to note that they were wrong and that an extra foot needed to be added to the average depth of the Thames (Ferguson 1832b; Ferguson 1832c). Sadly typical of Ferguson's inability for satire is the fact that more than fifty years after ridiculing what he called "the mania of the March-of-Machinery men" (Ferguson 1832b) he himself in all seriousness suggested a method for doing the same under the Liffey, thus avoiding a railway bridge which would obscure the vista of the Customs House (Patten 2004: 9).

Ferguson's career then was significant, diverse and public. His campaigning, in the most sweeping terms, for the esteem of Irish culture makes him an important and in the end polyvalent figure, mainly because of his apparently liberal and insistent inclusion of Protestant Ireland as integral to any full definition of Ireland. But this is a deceptively banal way to put it. Ferguson's legacy is unsurprisingly disputed, as is the nature of most Irish legacies. While the sometimes less than impressive body of work he left behind makes him all the more likely to be ignored or passed by quickly in literary and cultural history, in recent years the significance of Ferguson as a writer, perhaps more than the content of his actual work, has been the occasion of some low-level tug-of-war within Irish critical writing, in ways that are useful to know before thinking about how his fascination with Scotland might change the way we see his work. The Ulster Historical Society, rightly proud of having sponsored a blue plaque on Ferguson's place of birth in High Street in Belfast, summarised Ferguson's politics as unionist, Celtic, antiquarian and anti-violence. Despite the qualifications, such very northern views of Ferguson place him in the court of unionism. In contrast Henry Boylan's Dictionary of Irish Biography plays up his antiquarian work, his translations from the Irish and the céad mile fáilte of his hospitality, while glossing over one of his most sectarian pieces of writing, 'Father Tom and the Pope', by describing it as a "satire on Irish education” (Boylan 1998: 129). Such depressingly predictable north-south snapshots find themselves made more complex in academic criticism where Ferguson's name has, slightly half-heartedly at times, been associated with the search for a revision or liberalisation of political potentialities in the North. In his lecture 'Varieties of Irishness', delivered in 1988 with all the hopeful plurality that revisionist historiography could then muster, Roy Foster queries the very idea "that cultural diversity was inevitably confrontational", and Foster goes on to note that "Victorian Ireland could be middle-class, English-speaking and non-separatist in its politics, but no less Irish for that. Samuel Ferguson is the figure most instanced here" Foster 1989: 9, 10). Ferguson can be read into this history that never happened in the same way that the non-sectarianism of the United Irishmen can lead to a long lament for days of greater vision now lost. The overlapping pluralisms which Ferguson circulates around are, of course, telling of our own, contemporary concerns. As ever, such liberalism can be blind to the forces of atavism that it seeks to outwit by its decent logic. Edna Longley was to note just two years after Foster's lecture that Ferguson's simultaneously unionist and Irish credentials had not gone unnoticed within what passes for intellectual and literary unionism (Longley 1990: 8). In 1980 Ian Adamson produced an edition of Ferguson's Congal, retitled, presumably in a spirit of Ulster place-name pride, The Battle of Moira (Ferguson 1980). For Adamson, later to be unionist Lord Mayor of Belfast, Ferguson fulfilled his Cruthin thesis, which, whatever its merits as history, had more than a whiff of a Larne-Stranraer crossing to a Rangers-Celtic match about it (see Adamson 1991). Ferguson, Adamson suggests, "felt in his heart as an Ulsterman” (Adamson in Ferguson 1980: xviii) that his version of the battle at Moira was right, and what Adamson, as an Ulsterman, 'shows', is that Ulstermen now are as Ulstermen always were, and that their sojourn in Scotland was a temporary trip away from home. Adamson, now an MLA in the Northern Ireland Assembly, has continued to promote the notion of Ferguson's importance as an Irish unionist, going so far as to suggest in official questions 
in the Assembly (AQO 1058/01) that Ferguson's works, and Congal in particular, be held up as "an example of our shared inheritance in this Golden Jubilee year" (the 'jubilee' in question was, of course, the fiftieth anniversary of Queen Elizabeth II's reign: see Northern Ireland Assembly 2002). Ferguson's dalliance in Adamson's hands came close to tipping over into what Edna Longley describes as 'mutterings' from the UDA in the 1980s about their suppressed Irishness (Longley 1990: 8), and this is simply another point on that spectrum of attempted recuperations of Ferguson for a superficially pluralist politics.

The trouble with this is that Ferguson's politics were not particularly pluralist, even if his cultural vision was. In the 1980s, when the Cultural Traditions Group (which sponsored Foster's 1988 lecture) pondered the idea that cultural knowledge might heal political division, the possibility that Ferguson was an example of how to be happily Irish and unionist at the same time remained tempting (though this role was mainly taken by the often equally unsuitable twentieth-century Ulster poet John Hewitt). Scotland and Ulster-Scots identity have had a role to play in this tentative identity matrix, but a closer look at Ferguson's association with and views on Scotland show that sectarianism presides over pluralism in his vision, and that his Britishness is founded in his sense of his own class position, his Toryism and his unmitigated love of the British empire, which collectively seems like enough to repel the bravest of liberal readings. That said, Scotland is the site in which Ferguson frequently tests out how to configure Irish difference, and, most importantly, how tactically to place Ireland over against England in order to further his goal of bringing Ireland to the centre of the union, giving it, to twist a phrase, 'parity of esteem' within the United Kingdom.

A curious key to understanding any aspect of Ferguson's writing career is in knowing how, sometimes rather cruelly, he felt himself overshadowed by English literature in general, but in much more personal terms by the figure of Alfred (later Lord) Tennyson. Late in his life Ferguson's much-laboured over Congal was robbed of any impact it might have by Tennyson's Idylls of the King (both poems were published in supposedly final versions in 1872) (see Graham 1998). This must have been further confirmation for Ferguson of what the poem Congal already textually foretold - that Tennyson was always to be read and Ferguson would not. Congal was written while Idylls of the King was being published serially, and Ferguson's poem explicitly tries to outdo Tennnyson's at several points. William Allingham, a younger Irish poet and friend of both Ferguson and Tennyson, complained to the Poet Laureate, with little apparent response, that no one read Ferguson (Allingham 1967: 288, 348). Tennyson's inadvertent one-upmanship over Ferguson began as early as was conceivable; the first poems which Ferguson had published in Blackwood's were a translation of Beranger, published as "Roger Goodfellow", and "The Forging of the Anchor", both of which appeared in North's "Noctes Ambrosianae" in February 1832 (North 1832). Immediately following Ferguson's translation from the French, North and his sidekick Tickler consider the current miserable state of English poetry and hope for better once the Reform Bill is out of the way, so that a new generation can flourish. Disconcertingly for Ferguson (whose poem has just preceded this), North sees only one hope on the poetic horizon. North's pessimistic "The future is all darkness" is followed by his comment: "I have good hopes for Alfred Tennyson ... He has a fine ear for melody and harmony too - and rare and rich glimpses of imagination. He has - genius" (North 1832: 277). A few pages later, after some more praise and warning in equal measure for Tennyson, North prints Ferguson's poem "The Forging of the Anchor”, a curious ship-building poem with a line in industrialism and manliness which North praises with the words "the world will yet hear of the writer. Belfast gave him birth - I believe - and he bears the same name with a true poet of our own Scotland Fergusson [sic]. Maga will be proud of introducing him to the world" (North 1832: 283). Ferguson was of course delighted with his early success (he was at the time only twenty-two years old) and wrote to Blackwood's that "the honorable mention of my name with The Forging of the Anchor gave me the proudest satisfaction”. He enthusiastically went on:

I had intended The Forging of the Anchor as the first of a series, and (if you please, and I can do the subject justice within the time) I propose [?] forwarding along with the tale a 
similar piece entitled “The Felling of the Mast”. The other subjects which I had in contemplation are 'The Bearing of the Standard' \& 'The Launching of the Ship'.

(Ferguson 1832d)

Perhaps mercifully this youthful nautical series never materialised, but Ferguson kept a regular correspondence going with 'Maga', writing in May of 1832:

Tennyson may be well pleased with the last half of his notice which gave me a pleasant surprise as I had seen only the severe [?] introduction I was trembling for a writer whom I admire so much.

(Ferguson 1832e)

So from this first moment of his appearance in Blackwood's Ferguson was bound into a critical framework which named his roots as Belfast, linked him to Scotland, but saw his poetry as inevitably dimmed by the rising star of Tennyson. The shadow of Tennyson dogged Ferguson's relations with Blackwood's until the end of his life. In a letter to Robert Blackwood forty-six years later in 1878 Ferguson writes:

My dear Blackwood

I think it will give you pleasure to know that I am about to receive the honor of knighthood; \& that the reward is first on the grounds of literary as well as official services. I see that Tennyson offers us a ballad [?] in the forthcoming Nineteenth Century. His treatment will I dare say be better than [?] any other hand, but I am sure that his subject will not be as good as that of the little poem I enclose. I have also been printing a volume of such [?] for publication here in the autumn, \& if you care to have it, I [?] first use of it this one at your disposal; \& if you don't like it - I know you have no liking for our barbarian rudiments - you know me long enough ...

(Ferguson 1878)

So even at this moment of glory, when Ferguson's career is recognised by the state, Tennyson intrudes as an established and English presence, and, as the tetchy phrase "barbarian rudiments" shows, Ferguson has also moved away from his previous proximity to both the magazine and Scotland. The story of Tennyson's passive dogging Ferguson doesn't stop there; when Yeats wrote his two obituaries of Ferguson in 1886 his point of comparison was also Tennyson, suggesting that "If Samuel Ferguson had written of Arthur and Guinevere, they [the critics] would have received him gladly” (Yeats 1989: 89). Years later, incidentally, Hugh MacDiarmuid found himself, in his essay 'Contemporary Scottish Literature and the National Question', forcefully quoting Frank Harris's view that James Thomson's gifts of "genius" had been eclipsed by Tennyson, a poet "with the mind of a sentimental schoolboy” (MacDiarmuid 1969: 209), thus replicating in Scottish form Ferguson's Irish irritation with the Laureate.

For the very reason that poetry in English was pre-determined in its reception in the nineteenth century along the lines of imperial centrality, embodied in Tennyson, Ferguson's forays into literary criticism reveal a continual obsession with the centrifugal forces at work in the canon. Ferguson's review of James Hardiman's book Irish Minstrelsy, published in Dublin University Magazine in 1834, stands now as probably his most notable intellectual contribution to Irish literature (Ferguson 1834a; 1834b; 1834c; 1834d). In this four part review of a book of Irish language poetry in translation Ferguson retranslated many of the poems Hardiman himself translated (see especially Ferguson 1834d), and Ferguson's line, to put it in the broadest terms, is that Hardiman has assumed an exclusive, essentialist and Jacobite politics in his versions from the Irish. Ferguson's apparent liberalism is expressed in terms typically startling for us today, declaring himself "one of the number of those who can feel for, and sympathise with, the poor Papist” (quoted in Storey 1988: 33) (an unabashedly sectarian language which Ferguson echoes several times in his correspondence with Blackwood's on the assumption that it chimes with William, and later Robert, Blackwood's own prejudices). Ferguson uses the review to set out the flickerings of an agenda for English-Irish language fertility in Irish poetry - but more important to him is to address what he refers to as "the Protestants of Ireland" who "are wealthy and intelligent beyond most classes ... in the world", and to call on them to embrace "a thorough knowledge of the genius and disposition of their Catholic fellow-citizens" (quoted in Storey 1988: 34). Ferguson's Irish literary aesthetics were to be forever torn by this mission to educate Irish Protestantism into a Victorian patriotism - what is perhaps forgotten in the many accounts of the Hardiman review is that the Ferguson's 
original idea for the review was, as Peter Denman pointed out some years ago, that it should be published in Blackwood's (Denman 1990: 18). Indeed from the correspondence held in the National Library of Scotland, which includes only Ferguson's letters to Blackwood, it seems that Blackwood's encouraged and even commissioned the review as an extended series. Ferguson himself, once the four-part review was finished, had some anxieties that its content was not what Blackwood's wished. Writing to William Blackwood in November 1833 he says: "You will find in No 1 of the Minstrelsy that I have said somethings [sic] too broadly” (Ferguson 1833). Whatever reservations are hidden behind this caveat Blackwood's never published the Hardiman review and Ferguson was quick to let Blackwood know that Dublin University Magazine had taken it up.

Ferguson later regretted the tone and harshness of his review of Hardiman's translations. By the 1840s new possibilities for Irish poetics and politics seemed to be flourishing in the Young Ireland movement. Ferguson had a regard for their endeavours, if not for their politics. Ferguson eventually tried to reshape the legacy of Thomas Davis, the Young Ireland poet he most admired, in much the same way as in the Hardiman review he had opened out the Irish poetic tradition to conceivably non-nationalist reading (see Graham 1998: 85-92 and Denman 1990: 63$67)$. The vagueness of what this poetry might be, and how it might look, was made more precise by the Hardiman review on one side, and, on the other, by the Davis which Ferguson fancifully constructed in 1847. But between these there is, crucially, his two-part article from Dublin University Magazine on Robert Burns (Ferguson 1845a and 1845b).

Ferguson's essays on Burns, published in 1845, the year of Davis's death (though published before Davis died), show the shadows of Ferguson's thinking on how poetry could be national and unionist at the same time. Beginning with an extract from Swift's poem "On Poetry: A Rhapsody" ("Not beggar's brat, on bulk begot,/ Nor offspring of a pedlar Scot"- Ferguson has inserted the word "offspring" in place of Swift's "bastard"), whose satiric mind is condemned by the article, Ferguson reminds his Irish readers of what he calls the "contempt and hatred for Scotland and the Scottish people, which, just before the generation of Burns, flowed in a torrent ... from so many of the ablest pens" (Ferguson 1845a: 66). The future trajectory of the article is set from here; Burns is to be regarded as the figure largely responsible for the elevation of Scotland's intellectual fortunes, a notion which implies a particular role for the poet as cultural leader and which Ferguson derives from his reading of the past, evidenced in his remembrance of how "the bard could put an end to the battles of the Gauls, by shaking his chain of silence" (Ferguson 1845a: 67), a figure of the poetlegislator which reappears in a more beleaguered form in Congal. At the end of his first essay on Burns Ferguson expresses the hope that Young Ireland and the poets of The Nation newspaper will update this figuration Ferguson's ultimate interest in Burns, simmering below the surface throughout, is a belief that Burns (and more precisely, his version of Burns) is the model which Irish poetry needs to replicate. And further below the surface there is the always implied political structure - Scotland, the Scots and their literature were disregarded before Burns, and therefore disregarded by the court of cultural arbitration which is England. Ferguson's inherent unionism can never shake off this awkward political dynamic, and thus the regard of England is both sought and resented.

For Ferguson, Burns is not only a Scottish, and therefore an enviably national poet, he is a national poet of a particular kind. Ferguson therefore has to gloss over Burns's more salacious side (much as he would later brush off what he decided, against all evidence, was Thomas Davis's youthful enthusiasm for violent nationalism). And so Burns is above all the ploughman poet, Ferguson suggests, launching into a bizarrely homoerotic paean to the arts of ploughing, sowing and threshing. Burns is imagined as a

big-boned, stout-built, and vigorous man ... There are few more perfect pictures of unconquerable toil, than that of the mower standing for the length of a summer's day at this monotonous continuous labour, swaying the upper part of his body from side to side with the successive strokes of his scythe, while his lower limbs advance him by slow degrees into the thick meadow.

(Ferguson 1845a: 71) 
Burns as ploughman is a figure, Ferguson suggests, comparable to Homer's Ulysses in book XVIII of The Odyssey (making him also, incidentally, a figure comparable to Tennyson's Anglicised colonial "Ulysses", in the poem of that title published three years earlier). For Ferguson, Burns becomes depoliticised, and thus not a Jacobite, but rather a manly symbol of rebuke to the laziness of the landlord class, he who seeks "content ... in vain with his dog and gun, or even his rentdevouring pack of hounds" (Ferguson 1845a: 72 ) - and so Burns, whose conservative virtues Ferguson sees against all evidence, will eventually transform into the Davis of Ferguson's “Lament” for Davis, and Davis's politics will also come to be regarded as a reasonable protest at the long-standing ineffectuality of the Irish landlord class. Burns is also a poet of place, and the spirit of place and locality, for Ferguson, has a restraining influence on the excesses of politics while simultaneously explaining the vigours of manly youthfulness. By the time he writes his poem and article on Davis, two years later (Ferguson 1847), Ferguson has settled many of these issues into a more knowable pattern of thought - so the paragraph which begins his second article on Burns praises Burns's virtues and explains away his vices by turning into a rhythmic piece of prose which regales in turn the effect of the river, the mountains, the fields and the stars on the poetic imagination. The 'Lament for the Death of Thomas Davis' not only mourns Davis's passing, and not only rereads his politics as tending towards the conservative; the poem also confidently replicates the assurance of nature's and locality's own conservative sensibilities, affirmed through reading Burns, in its stanza structure, in which Davis is remembered, in each of the first three stanzas, through a place (Ballinderry, Ballyshannon, Derrybawn) and by the elements of nature: the eagle, the tree, the salmon, mountains and rivers. Most importantly Davis is recalled and eventually politically reconfigured, through the metaphor of ploughing and sowing:

I walked through Ballinderry in the spring-time, When the bud was on the tree;

And I said, in every fresh-ploughed field beholding The sowers striding free,

Scattering broad-cast forth the corn in golden plenty, On the quick seed-clasping soil,
Even such, this day, among the fresh-stirred hearts of Erin,

Thomas Davis, is thy toil!

(Ferguson 1847: 190)

As Burns seeps into Davis so Ferguson is able to give substance to the vision he has of an Irish poetics which proclaim place but not politics, which are replete with manliness but not excess, and which will, through the force of nature and its transcendent embodiment of a nation culture, ensure the future under, or just maybe outside, the union.

Such is Ferguson's developing view in the early 1840s. The trauma of the Famine, and the changed political circumstances which pertained after the Famine, mean that this was to some extent the zenith of Ferguson's hope for Irish culture. Ireland after the famine is transformed in terms of class structure and in its political obsessions - gone is the idealism that Ferguson admires in Young Ireland, to be replaced by a focus on land as an economic entity. By the time of Congal, 1872, the souring of Ferguson's vision, derived from Burns the ploughman poet, and replicated in that stanza to Davis, is readily seen in one of the scholarly endnotes to the poem, in which Ferguson recounts walking over the battlefield site at Moira: "I learn with deep regret, and some shame for my countrymen of the North, that [the ancient] memorial [to the battle] exists no longer. It has been destroyed by the tenant" (Ferguson 1872: 231). Ferguson notes that it was still there in 1842, at that time of hope when he was writing about Burns and then Davis, but that since then it has been removed. This despair is reflected in the very lines which the note refers to. The printed version of the poem has the lines:

The hardy Saxon little recks what bones beneath decay,

But sees the cross-signed pillar stone, and turns his plough away.

(Ferguson 1872: 107)

The ploughman here has lost that intimate feeling of nationality which Burns the ploughman poet had for Scotland, and which Davis recalled so strongly, in the cascading images of ploughing and sowing which Ferguson uses to dress Davis's Burnsian legacy. The nationalising of this moment is complex, and the word 'Saxon' is its saving 
grace, a strange nomenclature in the context and one that suggests the ethnic roots of this particular farmer, or maybe his political affiliation. Ferguson's deliberateness in constructing this model of the poet as a kind of organic farmer for the nation is emphasised by the fact that the original manuscript version from 1861 has different lines:

The careless rustic little thinks whose bones beneath abide;

But sees the cross-signed pillar stone, \& turns his plough aside.

(Ferguson 1861)

This progressive malaise in which a proper national poetry is being lost rather than created is central to the poem. The poets, those ancient lawgivers and peacemakers, are significantly marginalised in Congal from their previously central role in pre-Christian Ireland, sheltering under the care of Congal himself in Ulster; the coherence of Ireland is under threat in the poem, and Congal's search for allies on mainland Britain means that he returns to Ireland with his forces, his "hireling stranger[s]" (Ferguson 1872: 48) as calls them, to be met with hostility from the forces of nature (the cliffs of Antrim drip with blood as his ships approach them, for example, in an inversion of the old Viking myth of the red hand). This displacement of Ferguson's old ideals circles back on him until it soils his disturbs his view of Scotland. In one of those anachronistic passages I referred to at the beginning of this essay, Ferguson, losing control of the awkward allegories which force their way into his narrative, digresses to consider the ancient origins of shifting power balance which lead Scotland into the structure of the Union:

And after Selvach, once again to shift the wandering throne,

Came conquering Kenneth Alpinson, the first who sat at Scone,

Full King of Scotland, Gael and Pict; whose seat today we see

A third time moved, there permanent and glorious to be,

Where, in Westminster's sacred isles, the Three-

Joined-Realm awards

Its meed of solemn sepulture to Captains and to Bards;

And to the hands pre-designate of awful right, confides

The Sceptre that confers the sway o'er half of ocean's sides.

(Ferguson 1872: 107)
It is in acceptance of this long-standing "Three-Joined-Realm" that Ferguson now finds his solace, with Poet's Corner the last unhappy refuge of an ancient poetic tradition. By Celticising the imperial centre Ferguson squares the circle of his nationalism and unionism, but the tensions, partly through anachronism and partly through the forcing of the verse, are obvious. Five years after the publication of Congal Ferguson was still struggling with the unionist and imperial premise that dogs the cultural politics of Congal. He sent a poem to Blackwood's, to which he was now an infrequent contributor, entitled "The Widow's Cloak", a poem praising Queen Victoria's reign over Ireland and Scotland, but also gently rebuking her for visiting Scotland more often than Ireland (Ferguson 1877).

Ferguson's life and works then reveal how Scotland is interwoven with his writing career, his cultural politics and his gradual construction of a possible Ireland. As that Ireland rises to an apparent potential in the middle of the century, so Scotland takes on a more significant role; as Seamus Deane suggests, for Ferguson, "Scotland [was] a model on which Ireland and its relation to England could be based" (Deane 1997: 108). As Ireland drifted away from the vague form of cultural recognition Ferguson yearned for, so Ferguson's sense of Scotland as analogous to Ireland begins to break down, to be replaced with the coherence offered by an imperial polity, which can only be wistfully cast back into the distant past. Three years before he died Ferguson wrote to William Blackwood:

My dear Blackwood

I do not know whether you are aware that I have published some volumes of verse considered by myself at least to be in no way inferior to the Forging of the Anchor, but which so far have [illegible] little or no recognition either here or with you across the Channel. It may be that the fact of my being a Protestant \& Conservative on the one hand, \& of my publishing in Dublin \& taking Irish matters to so great an extent for my text, on the other, may account for this state of affairs.

(Ferguson 1883)

That Ferguson had to tell Blackwood that he had finally become an established poet, and that he did so by returning to a minor poem he had published through Robert Blackwood's father, William, fifty years earlier, is a marker 
marker of his distance from the publishing centre of Edinburgh which began and nourished his career. But even more significant is that the bond that was once there, made solid by a common Toryism unionism, an underlying sectarianism, and a patriot stubbornness, is now a chasm of nonrecognition. For Ferguson the crossing of St George's Channel by Congal and his hireling strangers is now finally an unbridgeable gap of cultural distance. A few years later Yeats, writing on "Scots and Irish Fairies" in the Scots Observer would breezily tell the Scots "you are too theological, too gloomy" (Yeats 1993: 27). Ferguson's taught and strained link to Scotland had finally been broken, to be replaced with a new generation's remodelled Celticism.

\section{Works Cited}

Adamson, Ian. 1991. The Cruthin. Belfast: Pretani.

Allingham, William. 1967. William Allingham's Diary. Fontwell: Centaur.

Boylan, Henry (ed.). 1998. A Dictionary of Irish Biography. Dublin: Gill \& Macmillan.

Deane, Seamus. 1997. Strange Country: Modernity and Nationhood in Irish Writing Since 1790. Oxford: Clarendon.

Denman, Peter. 1990. Samuel Ferguson: The Literary Achievement. Gerrards Cross: Colin Smythe.

Ferguson, Samuel. 1832a. “The Forging of the Anchor”. Blackwood's Edinburgh Magazine 21. 281-3. . 1832b. Letter to William Blackwood. National Library of Scotland MS 4032.265. 1832c. Letter to William Blackwood. National Library of Scotland MS 4032.267. 1832d. Letter to William Blackwood. National Library of Scotland MS 4032.249. . 1832e. Letter to William Blackwood. National Library of Scotland MS 4032.255. 1833. Letter to William Blackwood. National Library of Scotland MS 4035.215. 1834a. “Hardiman’s Irish Minstrelsy No. I”. Dublin University Magazine 3. 455-478 (first page misnumbered 465).

. 1834b. “Hardiman’s Irish Minstrelsy No. II”. Dublin University Magazine 4. 152-167.

. 1834c. “Hardiman’s Irish Minstrelsy No. III”. Dublin University Magazine 4. 447-467. 1834d. "Hardiman’s Irish Minstelsy No. IV”. Dublin University Magazine 4. 514-542.

1836. "Three Ballads: I. Una Phelimy II. Willy Gilliland III. Young Dobbs". Dublin University Magazine 7. 66-71.

. 1843a. Letter to Robert Blackwood. National Library of Scotland MS 4065.241.

1843b. Letter to Robert Blackwood. National Library of Scotland MS 4065.251.

1845a. "Robert Burns: First Article”. Dublin University Magazine 25. 66-81.

. 1845b. "Robert Burns: Second Article”. Dublin University Magazine 25. 289-305.

1847. “Our Portrait Gallery - No. XLII. Thomas Davis”. Dublin University Magazine. 29. 190-199.

1861. Manuscript of Congal. Linen Hall Library Ferguson Manuscripts.

. 1872. Congal: A Poem, in Five Books. Dublin: Edward Ponsonby.

1877. “The Widow’s Cloak”. Blackwood's Edinburgh Magazine 122. 742-743.

1878. Letter to Robert Blackwood. National Library of Scotland MS 4374.115.

. 1883. Letter to Robert Blackwood. National Library of Scotland MS 4444.59.

1980. The Battle of Moira, being the Epic Poem "Congal” by Samuel Ferguson. Newtownards: Newtownards Chronicle.

Foster, R.F. 1989. "Varieties of Irishness" in Cultural Traditions in Northern Ireland: Varieties of Irishness, edited by Maurna Crozier. Belfast: Insititute of Irish Studies.

Graham, Colin. 1998. Ideologies of Epic: Empire, Nation and Victorian Epic Poetry. Manchester: Manchester University Press.

Heaney, Seamus. 1984 (1983). Sweeney Astray. London: Faber and Faber. 
Longley, Edna. 1990. From Cathleen to Anorexia: The Breakdown of Irelands. Dublin: Attic.

MacDiarmuid, Hugh. (1969). Selected Essays of Hugh McDiarmuid. London: Jonathan Cape.

McBride, John P. 1987. 'The Dublin University Magazine: Cultural Nationality and Tory Ideology in an Irish Literary and Political Journal, 1833-1852 ‘, PhD thesis, Trinity College Dublin.

North, Christopher (pseudo. John Wilson). 1832. “Noctes Ambrosianae”. Blackwood’s Edinburgh Magazine 31. 255-288.

Northern Ireland Assembly. (2002). http://www.niassembly.gov.uk/record/reports/020319d.htm [retrieved $1 / 2 / 2009]$

Patten, Eve. 2004. Samuel Ferguson and the Culture of Nineteenth-Century Ireland. Dublin: Four Courts.

Storey, Mark. 1988. Poetry and Ireland since 1800: A Source Book. London: Taylor and Francis.

Yeats, W.B. 1989. Uncollected Prose. Vol. I. London: Macmillan

Yeats, W.B. 1993 (1889). 'Scots and Irish Fairies' in Writings on Irish Folklore, Legend and Myth. Harmondsworth: Penguin.

Colin Graham is the author of Ideologies of Epic: Empire, Nation and Victorian Poetry (1998) and Deconstructing Ireland: Identity, Theory, Culture (2001), and co-editor of Ireland and Cultural Theory (1999), Irish and Postcolonial Writing (2002) and Ireland and Europe in the Nineteenth Century (2006). He has also edited the poetry of Robert Browning and of Elizabeth Barrett Browning. He is currently co-editor of The Irish Review. He lecturers in English at the National University of Ireland, Maynooth. 